\section{SL-005＼cjkstart森田療法の100年一近年の広がりと 他療法との接点}

発表者：石山一舟 (ブリティッシュコロンビア大学)

司会者 : 堀毛一也 (東洋大学)

精神科医である森田正馬（1938-1874）が神経質治療のための特殊療法 として入院及び外来森田療法を開発し治療理論を確立し多くの臨床実践 例の報告を始めたのは100年も前のことである。以来，同療法は森田正馬 の直弟子や孫弟子にあたる多くの精神医学者を中心にメンタルヘルスや 心理の専門家および教育関係者によって脈々と受け継がれて今に至って いる。また，戦後徐々に海外に紹介されることが多くなり，近年では海 外でも森田療法の治療理念やその根底にある東洋的な人間観に基づく心 理療法, カウンセリング, 社会復帰のための援助法など多岐にわたり森 田療法の応用が実践されてきている。また，海外の治療的アプローチや 技法や治療概念の中には森田療法との接点や共通点が見られものがあり, 認知療法を基本とした治療法のいくつかは森田療法に近づいてきている と思われるものもある。このような日本内外に打ける森田療法の適用法 や応用法の拡大について述べ, 西洋で開発された治療法との相違点をい くつか指摘したい。

博士号 Ph.D. (ビクトリア大学 カウンセリング心理学)

ブリティッシュコロンビア大学教育学部准教授。同大学医学部精神医 学科参与兼任。研究分野は, 多文化間カウンセリングの指導法, 対人不 安の治療, 異文化適応，マイノリテイ差別への対応訓練法の開発。日本 森田療法学会より森田正馬賞を受賞 (2007年)。国際森田療法学会のプロ グラム委員, 日本森田療法学会常任理事, 同学会国際委員会事務局長。

\section{SL-006＼cjkstart意味を索（もと）めて：不確実性を 生きる}

発表者: 齋藤 洋典 (中部大学)

司会者: 大島 尚 (東洋大学)

人間の心のどんな側面の研究も容易ではないが, 中でも意識は心の解 明にとっての要でありかつ難関である。意識と同様に意味は人間理解に 重要な概念の 1 つである。両者の共通点は, 不確実な世界を生きるため に人間が進化の過程で獲得してきた生物的機能である。本講演では, 心 理学が人間の意味处理活動をいかに捉え, その解明にどのように関わっ てきたのかについて, 講演者が実施してきた意味をめぐる研究を交えて 述べる。

意識と情動と身体とが分離できないように，意味はそれらを離れては その意義を失う。意味は, 憧れや, 迷いや, 悔やみや, それら一切の矛 盾に立ち向かうことなく語られる時に, 解き明かす意義を失う。よって, 意識や意味は情動や行動を伴わない正解のない単なる心の難問ではない。 本講演では, 人類を脅かす感染症のパンデミック状況下にあるからこそ, 「言葉を超えて意味とは何かをみんなの問題として考える意義がある」と 提言する。

\title{
SL-007モチベーションの脳内制御機構とそ の破綻
}

発表者：南本 敬史 (量子科学技術研究開発機構)

司会者：石田 裕昭 (東京都医学総合研究所)

仕事や勉強，スポーツなど，日常の多くの行動を支え，その結果を大 きく左右するモチベーション（=意欲・やる気）は, 古くから心理学に おける主要テーマの一つであるとともに, 経済学, 医学, 教育, 経営な ど様々な分野で取り上げられてきた。神経科学の分野に打いてもモチベー ションは報酬や意思決定などとともに研究が進み, その制御の鍵を握る 物質（ドーパミン）や神経回路が解明されてきた。私たちの研究グルー プはヒトと近縁で発達した脳をもつサルをモデルとして, 報酬を獲得す るための行動のモチベーションについて心理学の理論をベースにした計 算アルゴリズムを導出し, ポジトロン断層撮影 (PET) などイメージン グや最新の化学遺伝学による神経回路操作を駆使することで，モチべー ションの脳内計算とその破綻の仕組みについて研究している。本講演で は, モチベーションの脳内処理機構や，うつなどの精神疾患でしばしば 見られる「意欲低下」との関連についても合わせて紹介する。 